\begin{tabular}{|c|c|c|}
\hline $\begin{array}{l}\text { FATIH } \\
\text { SULTAN } \\
\text { MEHMET } \\
\text { VAKK UNIIVERSIESI } \\
2010\end{array}$ & $\begin{array}{l}\text { FSM İlmî Araştırmalar Insan ve Toplum Bilimleri Dergisi } \\
\text { FSM Scholarly Studies Journal of Humanities and Social Sciences } \\
\text { Sayı/Number } 14 \text { Yıl/Year } 2019 \text { Güz/Autumn } \\
\text { (C2019 Fatih Sultan Mehmet Vakıf Üniversitesi }\end{array}$ & 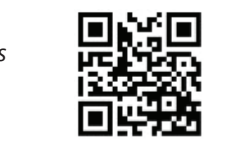 \\
\hline DOI: & http://dergipark.org.tr/fsmia & http://dergi.fsm.edu.tr \\
\hline Araştırma Makalesi / Research Article & Geliş Tarihi / Received: 13.10.2019 Kabul Tarihi / Accepted: 26.11.2019 & FSMIAD, 2019; (14): 313-326 \\
\hline
\end{tabular}

\title{
X, Y, Z Kuşaklarının Çocukluk Oyunlarının İncelenmesi ${ }^{*}$
}

İsa Kaya**

\section{Öz}

Oyun, çocuğun sağlıklı gelişmesi ve öğrenmesinde önemli bir role sahiptir. Teknoloji ve dijitalleşmenin gelişmesi insan yaşamında birçok değişikliğe yol açmışır ve farklı kuşaklarda çocukların oynadığı oyunlar bu değişimden etkilenmiştir. Bu çalışmada da belli bir kuşakta doğmuş ve çocukluğunu o kuşağın içinde geçirmiş bireylerin oyuna bakışlarını, oynadığı oyunları, oyun oynadığı mekanları ve materyalleri inceleyerek kuşakların oyun benzerlik ve farklılıklarının incelenmesi amaçlanmıştır. Nitel araştırma yönteminden durum çalışması deseni ile yapılan araştırmanın çalışma grubunu 20182019 eğitim öğretim yılında eğitim gören okul öncesi öğretmenliği bölümü öğrencileri ve aile bireyleridir. Çocukluğunu 1960-1980 yılları arasında geçirmiş büyükanne ve büyükbabalar X kuşağını, çocukluğunu 1980-2000 yılları arasında geçirmiş anne ve babalar Y kuşağını, çocukluğunu 2000 yılından sonra geçirmiş öğrencilerin kendileri Z kuşağını oluşturmuştur. Veriler araştırmacı tarafindan geliştirilen açık uçlu soruların yer aldığı form ile toplanmıştır. Çalışmanın sonucuna göre $X$ kuşağı oyunu çocuk işi ve çocuğun ihtiyacı olarak görürken, Y ve Z kuşağı eğlendirici faaliyet olarak tanımlamıştır. X, Y, Z kuşaklarının üçünde de saklambaç ve mendil kapmaca tercih edilen oyunları oluştururken Z kuşağının oyun tercihleri arasında bilgisayar oyunları ve televizyon izlemek gibi aktivi-

\footnotetext{
* Bu çalışma 26,27 Nisan 2019 tarihinde İspanya'da “İnternational Congress Teleseict” kongresinde sözlü bildiri olarak sunulmuştur.

** Dr. Öğr. Üyesi, Fatih Sultan Mehmet Vakıf Üniversitesi Eğitim Fakültesi Okul Öncesi Öğretmenliği Bölümü, İstanbul/Türkiye, kayaisa55@gmail.com, orcid.org/0000-0003-3604-1368
} 
telerin de yer aldığı görülmüştür. X ve $Y$ kuşağının oyun materyallerinde çamur, toprak, taş, çubuk, sopa gibi doğal malzemeler bulunurken $\mathrm{Z}$ kuşağında doğal oyun materyallerin yerini oyuncaklar, bebekler, boya kalemleri gibi endüstriyel ve yapay oyun materyalleri yer almıştır. X ve Y kuşağının oyun alanlarını açık alanlar, Z kuşağının oyun alanlarını kapalı alanlar oluşturmuştur.

Anahtar Kelimeler: X, Y, Z kuşağı, oyun, oyun mekânları, oyun materyalleri.

\section{Investigation of Childhood Games in the Lives of X, Y, Z Generations}

\section{Abstract}

Play has an important role in the healthy development and the learning of the child. The development of technology and digitalization has led to many changes in human life. Type of plays children are involved from different generations has been influenced by this change. This study was carried out to examine the perceptions and experiences of people from different generations (X, Y, and Z Generations) about their childhood plays in terms of types, materials, and playgrounds they preferred in their childhoods. In this research, case study which is one of the qualitative research methods was used. The data were collected from the pre-service early childhood education teachers, their parents, and their grandparents throughout the 2018-2019 academic year. X generation includes the people lived their childhoods during the 1960-1980 years. Y generation includes the people lived their childhoods during the 1980-2000 years. Z generations includes the people lived their childhood since 2000 years.

Data was collected via semi-structured interview form developed by the researcher. According to the results of the study, while generation $\mathrm{X}$ evaluated the play as child's work and the need of the child, generation $\mathrm{Y}$ and $\mathrm{Z}$ defined it as entertaining activity. While hide and seek, handkerchiefs were the most preferred plays in all three generations, it was seen that generation $\mathrm{Z}$ was involved in activities such as computer games and watching television. While the play materials of generation $\mathrm{X}$ and $\mathrm{Y}$ were natural materials such as mud, soil, stones, sticks, sticks, industrial, $\mathrm{Z}$ generation mentioned from artificial play materials such as toys, dolls, crayons. While the $\mathrm{X}$ and $\mathrm{Y}$ generations choose open playgrounds, it seen that the $\mathrm{Z}$ generation prefers indoor playgrounds more.

Keywords: X, Y, Z generation, play, playgrounds, play materials. 


\section{Giriş}

Kuşak kelimesi Türk Dil Kurumu sözlüğünde "yaklaşık olarak aynı yıllarda doğmuş, aynı çağın şartlarını, dolayısıyla birbirine benzer sıkıntıları, kaderleri paylaşmış, benzer ödevlerle yükümlü olmuş kişilerin topluluğu" olarak tanımlanmıştır. ${ }^{1}$ McCrindle and Wolfinger (2009)² e göre kuşak, benzer özellikler gösteren, zamanı ve mekânı paylaşan insan topluluğudur. İçinde bulunduğumuz yüzyılda ortaya çıkan kuşaklara baktığımızda bazı kuşaklar ön plana çıkmaktadır. Birinci ve ikinci dünya savaşlarının arasında doğan "sessiz kuşak" bunlardan birisidir. Bu kuşağın en önemli olayı İkinci Dünya Savaşı'nın zorluklarını yaşamasıdır. “Sessiz kuşak”tan sonra İkinci Dünya Savaşı'nın bitmesiyle birlikte "bebek patlaması kuşağı" ortaya çıkmıştır ve bu kuşakta bebek doğumlarında ciddi bir artış gözlenmiştir. Bu kuşak sessiz kuşağa göre daha rahat bir ortamda büyümüştür. ${ }^{3}$ Bu iki kuşaktan sonra 1965-1979 yılları arasında X kuşağı ortaya çıkmıştır ve bu kuşak ekonomik krizlerden ve sosyal olaylardan etkilenen bir kuşaktır. Bu kuşağın bireylerinin iş sadakati yüksektir ve bu kuşak teknolojiyi zorunlu işlerinde kullanır. 1980-1999 yılları arasında ortaya çıkan Y kuşağının en önemli özelliği özgürlüğüne ve teknolojiye düşkün olmalarıdır. Y kuşağı X kuşağına göre çalışmayı sevmez ve kolay iş değiştirirler. Bu kuşak yüksek özgüvene ve kararlı bir yapıya sahip, konfor alanını kolay terk eden, değişime ve yeniliğe açık, otoriteden hoşlanmayan bir kuşaktır. 2000 yılından sonra ortaya çıkan ve halen devam eden $Z$ kuşağ 1 ise, teknolojinin içinde doğan ve yaşayan kuşaktır. Z kuşağı interneti ve sosyal paylaşım sitelerini sosyalleşme aracı olarak kullanır. Bu kuşağın dikkat süresi kısadır ve bu kuşağın bireyleri aynı anda birden fazla işi yapabilme kapasitesine sahiptir. Çabuk sıkılan, çabuk tüketen ve hızlı yaşayan bir kuşaktır. Yaşadıkları her anı, sosyal medyada paylaşırlar. Duygu ve düşüncelerini çekinmeden söylerler, diğer kuşaklarla çatışma yaşarlar. ${ }^{4}$

Belli bir amaca yönelik olan veya olmayan, kurallı ya da kuralsı gerçekleştirilen fakat her durumda çocuğun isteyerek ve hoşlanarak yer aldığı, fiziksel, zihinsel, dil, duygusal ve sosyal gelişiminin temeli olan, gerçek hayatın bir parçası ve çocuk için en etkin öğrenme süreci olarak tanımlanan oyun ${ }^{5}$ bütün kuşaklarda var olmuş ve etkinliğini sürdürmüştür. Oyunun biçimi, özelikleri, oyun araç gereçleri

1 TDK, Türk Dil Kurumu Sözlüğ̈̈, https://tdk.gov.tr/, 2019.

2 Mark McCrindle - Emily Wolfinger, The Abc of Xyz: Understanding the Global Generations, Avustralya, University of New South Wales, 2009.

3 Pınar Başgöze - Nalan Bayar, "Eko Otellerden Hizmet Satın Alımında Kuşaklar Arası Farkl1laşmalar Üzerine Bir Çalışma”, Sosyoekonomi, cilt 23, sayı 24, 2015, ss. 118-30.

4 Mark McCrindle - Emily Wolfinger, a.g.e.

5 Necate Baykoç Dönmez, Oyun Kitabı, İstanbul, Esin Yayınevi, 1992. 
çağdan çağa, kültürden kültüre değişse de çocuğun bulunduğu her yerde oyun vardır. Dünyanın her yerinde, her kuşakta, her kültürde oynanmış, oynanmaya devam etmektedir. Arkeolojik araştırma ve yazılı belgelerde günümüzde oynanan oyunların 2000 yıl ve daha öncesine dayandığını anlaşılmaktadır. "Sek Sek" gibi oyunların izine Roma harabelerinde de rastlanmaktadır. Benzer bir şekilde "tura oyunu, topaç çevirme, saklambaç, denizin üzerinde taş kaydırma oyunu, çatal-matal, körebe" ve benzeri türden oyunlar, çok eskiden beri oynanan oyunlardır. Bulgular, oyunların isimleri değişse de ülkeden ülkeye benzer şekillerde, benzer materyallerle oynandığını göstermektedir. ${ }^{6}$ Yeni yüzyılın insanlara sunduğu olanaklar, çocukların oyun dünyasını da etkilemiştir. Oyun yaşamındaki değişim sadece nicel boyutta kalmamış oyun türlerini, içeriklerini, oyun mekânlarını ve oyun araçlarını da değiştirmiştir. Özellikle teknoloji ve oyuncak endüstrisindeki buluşlar, gelişmeler ve yenilikler bu değişimi daha da hızlandırmıştır. Bu değişimle birlikte çocuklar doğal oyun ortamlarından uzaklaşarak daha çok bireysel, kapalı alanlarda ve teknolojik araçlarla oynamaya yönelmiştir. ${ }^{7}$ Kapalı mekânlarda oyun oynayan çocukların oyunlarında çeşitlilik, yaratıcılık, işlevsellik azalırken teknolojik materyallerle oynama davranışları artış göstermiştir. Akçay ve Özcebe'nin ${ }^{8}$ 2012 yılında yaptığı araştırmada çocukların \%44.1'inin bilgisayar oyunu oynadığını göstermektedir. İçinde bulunulan Z kuşağının çocuklarının açık alanlarda yaşıtlarıyla oyunlar oynamak yerine kapalı mekanları tercih etmeleri açık oyun alanlarının sağlayabileceği fırsatlardan yoksun kalmalarına neden olabilmektedir. ${ }^{9}$ Koçyiğit ve Baydilek-Başara ${ }^{10}$ yaptıkları araştırmada çocukların genelde evlerinde tek başlarına oyunlar oynadıklarında, çocukların arkadaşlık ilişkilerini, yaratıc1lıklarını olumsuz etkilendiğini bulmuşlardır. ${ }^{11}$ Geçmişten günümüze teknoloji, makineleşme, ekonomik ve siyasi gelişmeler kuşakların oluşmasında belirleyici olmuştur. Bu gelişme ve ilerlemelerin X, Y, Z kuşaklarında doğan ve çocukluklarını bu kuşakların içinde geçiren bireylerin oyuna bakışlarında, oyun oynadığ

6 Hatice Poyraz, Okul Öncesi Dönemde Oyun ve Oyuncak, Ankara, Anı Yayınc1lık, 2003.

7 Belma Tuğrul, “Oyunun Gücü”, Okul Öncesi Eğitimde Oyun, editör Ayşe Belgin Aksoy, Ankara, Hedef Yayınları, 2015, ss. 9-28.

8 Duygu Akçay - Hilal Özcebe, "Okul Öncesi Eğitim Alan Çocukların ve Ailelerinin Bilgisayar Oyunu Oynama Alışkanlıklarının Değerlendirilmesi”, Çocuk Dergisi, cilt 12, sayı 2, 2012, ss 66-71.

9 Ayşe Belgin Aksoy - Hale Dere Çiftçi, “Oyun Alanı Materyal ve Oyuncaklar”, Okul Öncesi Eğitimde Oyun, editör Ayşe Belgin Aksoy, Ankara, Hedef, 2015, ss 55-79.

10 Sezai Koçyiğit - Nisa Başara Baydilek, "Okul Öncesi Dönem Çocuklarının Oyun Algılarının İncelenmesi”, Yüzüncü Yıl Üniversitesi Eğitim Fakültesi Dergisi, cilt 12, sayı 1, 2015, ss. 1-26.

11 Belma Tuğrul - Gözde Ertürk - Şenay Özen Altınkaynak - Gökhan Güneş, “Oyunun Üç Kuşaktaki Değişimi”, The Journal of Academic Social Science Studies, cilt 27, 2014, ss. 1-16. 
mekanlarda ve materyallerde farkl1lıklar oluşturduğu düşünülmektedir. Bu çalışmada da belli bir kuşakta doğmuş ve çocukluğunu o kuşağın içinde geçirmiş bireylerin oyun bakışlarını, oynadığı oyunları, oyun oynadığı mekanları ve materyalleri inceleyerek kuşakların oyun benzerlik ve farklılıklarının incelenmesi amaçlanmıştır. Bu temel amaçla aşağıdaki sorulara cevap aranmıştır.
a. X,Y,Z kuşaklarının oyuna bakışları nasıldır?
b. X, Y, Z kuşaklarının çocukluklarında oynadığı oyunlar nelerdir?
c. X,Y,Z kuşaklarının oyun materyalleri nelerdir?
d. X,Y,Z kuşaklarının oyun oynadığı mekanlar nerelerdir?

\section{Araştırma Yöntemi}

Çalışma nitel araştırma yönteminden durum çalışması deseni ile yapılmıştır. Nitel araştırma farklı yöntemlerle tutum, davranış ve deneyimleri keşfeder, katılımcılardan derinlemesine fikirler elde eder. Önemli olan tutum, davranış ve deneyimler olduğu için araştırmada daha az kişiye yer verilir. ${ }^{12}$ Nitel araştırma nesnelerin anlamlarını, kavramlarını, tanımlamalarını, karakteristiklerini, metaforlarını, sembollerini ve tasvirlerini ifade eder. ${ }^{13}$ Mc Millan durum çalışmalarını bir ya da daha fazla olayın, ortamın, programın, sosyal grubun ya da diğer birbirine bağlı sistemlerin derinlemesine incelendiği bir araştırma olarak tanımlamıştır. ${ }^{14}$

\section{Çalışma Grubu}

Çalışma grubu, amaçlı örneklem ile seçilmiştir. Çalışma grubunu 2018-2019 eğitim öğretim y1lında okul öncesi öğretmenliği bölümünde eğitime devam öğrenciler ve aile bireyleri oluşturmuştur. Çocukluğunu 1960-1980 yılları arasında geçirmiş büyükanne ve büyükbabalar X kuşağını, çocukluğunu 1980-2000 yılları arasında geçirmiş anne ve babalar Y kuşağını, çocukluğunu 2000 yılından sonra geçirmiş öğrencilerin kendileri $Z$ kuşağını oluşturmuştur. Araştırma amacına uygun olarak X, Y, Z kuşaklarının her birinden 20'şer olmak üzere toplam 60 kat1lımcı ile yapılmıştır. X kuşağının 20 katılımcısının \%40'ını kadın, \%60'ını erkekler oluştururken Y kuşağındaki 20 katılımcının \%35'ini kadın, \%65'ini erkekler oluşturmuştur. Yine Z kuşağında katılımcıların \%90'ı kadın, \%10’u erkektir.

12 Catherine Dawson, Araştırma Yöntemlerine Giriş, çeviri editörü Asım Arı, Konya, Eğitim Yayınevi, 2015.

13 Buruce L Berg - Howard Lune, Sosyal Bilimlerde Nitel Araştırma Yöntemleri, çeviri editörü Hasan Aydın, Konya, Eğitim Yayınevi, 2015, ss.1-20.

14 Şener Büyüköztürk - Ebru Kılıç Çakmak - Özcan Erkan Akgün - Şirin Karadeniz - Funda Demirel, "Bilimsel Araştırma Yöntemleri”, 13. bs., Ankara, PegemAkademi, 2012. 


\section{Veri Toplama Aracı}

Veriler çalışmanın alt amaçları doğrultusunda araştırmacı tarafından geliştirilen açık uçlu soruların yer aldığ 1 form ile toplanmıştır. Araştırmacı tarafında literatür taraması yapılarak sorular oluşturulmuş ve oluşturulan sorular 3 alan uzmanı akademisyenin görüşüne sunulmuştur. 5 kişiyle pilot uygulaması yapı1dıktan sonra sorular son halini almıştır. Katılımcılara "Sizce oyun nedir? Çocukluğunuzda hangi oyunları kimlerle oynardınız? Çocukluğunuzda oynadığınız oyunlarda hangi materyalleri kullanırdınız? Nerelerde oyunlar oynardınız? " soruları yöneltilmiştir.

\section{Verilerin Analizi}

Verilerin analizi betimsel analiz ile yapılmıştır. Betimsel analizde durum mantıklı ve anlaşılır bir biçimde betimlenir, daha sonra yorumlanır ve neden sonuç ilişkileri irdelenerek sonuçlara ulaşılır. ${ }^{15}$ Verilerin analizi öncesinde katılımc1lar $\mathrm{X}$ kuşağ 1 için $\mathrm{X} 1, \mathrm{X} 2, . ., \mathrm{Y}$ kuşağ 1 için $\mathrm{Y} 1, \mathrm{Y} 2 \ldots, \mathrm{Z}$ kuşağı için Z1, Z2..., olarak kodlanmıştır. Geçerliğin sağlanması için katılımcıların cevaplarından doğrudan alıntılara yer verilmiştir.

\section{Bulgular ve Yorum}

Yöneltilen her bir soru için katılımcılardan elde edilen bulgular aşağıda sunulmuştur.

Tablo 1. X, Y, Z Kuşaklarının Oyuna Bakışları

\begin{tabular}{lclclc}
\hline X Kuşağı & f & Y Kuşağı & f & Z Kuşağı & f \\
\hline $\begin{array}{l}\text { Çocuk işi ve } \\
\text { ihtiyacı }\end{array}$ & 8 & Eğlendirici faaliyet & 9 & Eğlendirici faaliyet & 7 \\
$\begin{array}{l}\text { Eğlendirici } \\
\text { faaliyet }\end{array}$ & 5 & $\begin{array}{l}\text { Eğitici ve öğretici } \\
\text { aktivite }\end{array}$ & 4 & $\begin{array}{l}\text { Eğitici ve öğretici } \\
\text { aktivite }\end{array}$ & 6 \\
$\begin{array}{l}\text { Iletişim aracı } \\
\text { Fazla enerjiyi }\end{array}$ & 3 & İletişim aracı & 4 & Geleceğe hazırlanma & 5 \\
$\begin{array}{l}\text { boşaltma } \\
\text { Oyalanma } \\
\text { aracı }\end{array}$ & 2 & Fazla enerjiyi boşaltma & 3 & Fazla enerjiyi boşaltma & 2 \\
\hline
\end{tabular}

15 Ali Yıldırım - Hasan Şimşek, Nitel Araştırma Yöntemleri, 2. bs., Ankara, Seçkin Yayıncılık, 2000. 
Tablo 1 incelendiğinde X kuşağı bireyleri oyunu çocuğun işi ve ihtiyacı, eğlendirici faaliyet tanımlayarak görüşlerini şu şekilde ifade etmişlerdir. "Oyun çocuklar için yemek su kadar önemli bir ihtiyaçtır (X1), oyun çocuğun işidir (X17), çocukların eğlenmek için yaptığı hareketlerdir $(X 20)$ ". Y ve Z kuşaklarında ise oyunun eğlendirici faaliyet, eğitici öğretici aktivite olma işlevleri ön plana çıkmıştır. Z kuşağında bazı katılımcılar oyunu çocuğu geleceğe hazırlayıcı faaliyet olarak nitelendirmişler ve oyunun eğitici yönünü ortaya koymuşlardır. Z kuşağ1nın oyun sizce nedir sorusuna verdikleri cevaplar "eğlendirirken öğreten önemli bir ihtiyaç (Z10), oyun çocukların gelişimlerini devam ettirdikleri, öğrendikleri ve iletişim kurdukları bir iş (Z3), oyun ögrenme becerisi, hayat eğlencesi (Y9)" şeklinde olmuştur.

Tablo 2. X, Y, Z Kuşaklarının Çocukluklarında Oynadığı Oyunlar

\begin{tabular}{llllll}
\hline X Kuşağı & f & Y Kuşağı & f & Z Kuşağı & f \\
\hline Saklambaç & 17 & Saklambaç & 16 & Evcilik & 17 \\
Mendil kapmaca & 15 & Çelik çomak & 15 & Saklambaç & 16 \\
Çelik çomak & 15 & Uzun eşek & 13 & Televizyon izlemek & 15 \\
Körebe & 14 & Mendil kapmaca & 12 & İp atlama & 15 \\
İp atlama & 10 & Körebe & 10 & Sek sek & 14 \\
Sek sek & 9 & Misket & 9 & Bilgisayar oyunları & 13 \\
Beş taş & 7 & Futbol & 9 & Beştaş & 11 \\
Kızak kayma & 6 & Taş oyunları & 8 & Playstation & 10 \\
Halay & 6 & Valeybol & 8 & Birdir bir & 8 \\
Horon & 4 & Yakartop & 7 & Misket & 5 \\
Top & 3 & Elim sende & 7 & & \\
\hline
\end{tabular}

Tablo 2'de saklambaç oyunu her kuşakta çocuklar tarafindan ilgiyle oynanan bir oyun olma özelliğini korumaktadır. X ve Y kuşağının oyunları birbirine benzemektedir. Her iki kuşakta mendil kapmaca, çelik çomak, körebe, ip atlama oyunlarını oynandıkları katılımcıların verdiği cevaplardan anlaşılmaktadır. Y kuşağında X kuşağından farklı olarak top oyunlarında artış görülmektedir. Katılımcılar, bu top oyunlarını futbol, voleybol, yakartop olarak tanımlamışlardır. Z kuşağının oyunlarında $\mathrm{X}$ ve $\mathrm{Y}$ kuşağına göre farklılık göze çarpmaktadır. $Z$ kuşağında bilgisayar oyunları, playstation ve televizyon izleme aktiviteleri diğer kuşaklarda görülmeyen sadece bu kuşağın oynadığı oyunlar ve yaptığı aktivitelerdir. Katılım- 
c1lar bu konudaki düşüncelerini şu şekilde ifade etmişlerdir. "Bezirganbaşı, saklambaç, körebe, seksek, oyuncak bebeklerle, boyama yaparak, bilgisayar oyunlarl ve çizgi film izleyerek vaktimi geçirirdim (Z18). Köyde yapılacak işlerde annemize babamıza yardım ederdik, hayvanları otlatırken oyun oynardık (X8)'”. Y kuşağ1nın oyunlarında çeşitlilik artarken Z kuşağının oynadığı oyunlarda çeşitlilik azalmıştır. Y kuşağının oynadığı oyunlardaki çeşitlilik Türk toplumunda 1980'lerden sonra tarımda makinelerin daha fazla kullanılmasıyla kırsalda yaşayan çocukların oyuna daha fazla zaman ayırabildikleri şeklinde yorumlanabilir.

Tablo 3. X, Y, Z Kuşaklarının Çocukluklarında Oynadığı Oyun Materyalleri

\begin{tabular}{llllll}
\hline X Kuşağı & f & Y Kuşağı & f & Z Kuşağı & f \\
\hline Çamur, toprak & 18 & Top & 16 & Top & 16 \\
Taş & 16 & Çamur, toprak & 15 & İp & 13 \\
Çubuk, sopa & 14 & Taş & 15 & Oyuncaklar & 10 \\
Misket & 13 & Çubuk, sopa & 13 & Bebek & 9 \\
İp & 13 & Misket & 12 & Taş & 7 \\
Topaç & 10 & İp & 11 & Boya kalemleri & 7 \\
Bez bebek & 9 & Araba lastiği & 10 & Kağıtlar & 6 \\
Tahta & 8 & Dal, yaprak, ot & 8 & Playstation & 6 \\
Dal, yaprak, ot & 8 & Bebekler & 8 & Kumandalı araba & 6 \\
\hline
\end{tabular}

Tablo 3 incelendiğinde de X kuşağının oyunlarında doğal materyaller ön plana çıkmaktadır. X kuşağının içinde bulunduğu şartlar, sosyal ve ekonomik sıkıntılar ve nüfusun büyük çoğunluğun tarımla uğraşması doğal materyallere ulaşımın kolay olmasını sağlamış olabilir. Yapay materyaller, bu kuşakta görülmezken doğada kolay bulunabilen çamur, toprak, taş, çubuk gibi materyallerin oyun materyali olarak kullanıldığı görülmektedir. X kuşağı oyun materyalleri ile ilgili düşüncelerini "Çok oyun oynamaya vaktimiz olmazdl. Genelde tarlada, hayvan otlatırken bazen de işten kaçıp oyun oynardık. Taş, sopa, yaprak ne bulursak oynardık (X4). Bizim çocukluğumuz hep mücadele ile geçti. Doğal materyallerden kendimize bir oyuncak yapma uğraşı içinde olurduk, kendi oyuncağımızı yapmanin keyfi farklı olurdu (X15). Bahçelerde, dağlarda, evde oynardık. Yapraktan bebek, ottan beşik, ă̆açtan çıkrık, findıkkabuğundan firıldak, minderden bebek yapıp oynardık (X16). Kardeşlerimle ve köyden arkadaşlarla birlikte açık havada sopalarla, çamurla oynardık (X20)" diyerek belirtmişlerdir. Y kuşağında ise doğal materyallerle birlikte topun da oyun materyali olarak kullanıldığı 
vurgulanmıştır. Katılımcılar "arkadaşlarımızda birlikte toprakla çamurla, bebeklerle oynardık, çamurdan pastalar, yemekler yapardık (Y20), günün büyük zamanında köyün boş tarlalarında top oynardık (Y12) diyerek oyun materyalleri ile ilgili düşüncelerini ifade etmişlerdir. İp, kâğıt, oyuncaklar, bebekler, teknolojik materyaller ve endüstriyel oyuncakların $\mathrm{Z}$ kuşağındaki çocukların oyunlarında sık sık kullandığı materyaller arasına girdiği tablodan anlaşılmaktadır. Z kuşağının cevapları şu şekildedir. "Çocukluğumda bilgisayar, playstation oyunları ve arada sokağa çıkarak arkadaşlarımla top ve oyunları oynardım (Z7). Ben çocukluğumda zamanımın çoğunluğunu evde geçirirdim. Oyuncaklarımla, bebekler, uzaktan kumandalı arabalar, lego, mutfak gereçleri vb. oyuncaklarla oynardım. Bazen de okul araç gereçlerimi oyunlarımda kullanır, boya kalemleri iler resimler yapardım (Z9).

Tablo 4. X, Y, Z Kuşaklarının Çocukluklarında Oynadığı Oyun Mekânları

\begin{tabular}{llllll}
\hline X Kuşağı & f & Y Kuşağı & f & Z Kuşağı & f \\
\hline Bahçe & 18 & Bahçe & 16 & Mahalle & 18 \\
Tarla & 16 & Sokak & 12 & Okul & 15 \\
Sokak & 14 & Dam & 12 & Bahçe & 15 \\
Köy meydanı & 12 & Mahalle & 10 & Evin içi & 15 \\
Ev & 12 & & & Apartman & 13 \\
Dağ & 11 & & & Sokak & 10 \\
& & & & Park & 8 \\
\hline
\end{tabular}

Tablo 4'te X ve Y kuşağının oyunlarında bahçe, tarla, sokak, köy meydanı gibi açık alanları daha çok tercih ettikleri görülmektedir. Katılımcılar "ben küçükken hiç oyuncağımız yoktu, evin önündeki sokaklarda genelde komşumuzun çocukları ve kardeşlerimle oynardım (X14). Köydeki işlerden zaman kalırsa tahtadan arabalarla oyun oynardım (Y3) " diyerek oyun oynadıkları mekânlarla ilgili görüşlerini ifade etmişlerdir. Z kuşağının oyun mekânlarını evin bulunduğu mahalle, okul, ev, apartman gibi kapalı mekanlar oluşturmuştur. Bu dönem çocukların kapalı mekânları daha çok tercih etmesinin nedeni Z kuşağının hayatına televizyon ve bilgisayar ve playstation gibi materyallerin girmesi olabilir. Z kuşağı bireyleri "zamanımın çoğunu evimizin bahçesinde, sokakta, parklarda arkadaşlarımla oyun oynayarak ve evde çizgi film izleyerek geçirirdim (Z19). Sokakta ve evde oyun oynardım, evimize yakın bir yerde park yoktu ve yeşil alanlarda pek oynamadım (Z4)" şeklinde soruları cevaplamışlardır. 


\section{Tartışma}

Bu çalışmada X, Y, Z kuşaklarında doğmuş ve çocukluğunu o kuşağın içinde geçirmiş bireylerin oyun bakışlarını, oynadığı oyunları, oyun oynadığı mekanları ve oyun materyallerini ortaya koyarak kuşakların oyunlarındaki benzerlik ve farklılıklarının incelenmesi amaçlanmıştır. Çalışmanın sonucuna göre X kuşağı oyunu çocuk işi ve çocuğun ihtiyacı olarak görürken Y ve Z kuşağı eğlendirici faaliyet olarak tanımlamıştır. Z kuşağının oyunlarında diğer kuşakların aksine kapalı mekanlar tercih edilmiştir. Yine Z kuşağının oyunlarında evcilik, bilgisayar oyunları ve televizyon izlemek gibi teknolojik oyunlar ve aktiviteler de yoğun olarak yer almıştır. Mevcut araştırmalarda benzer sonuçlara ulaşılmıştır. Tuğrul ve arkadaşlar ${ }^{16}$ oyunun üç kuşaktaki değişimine baktığ 1 araştırmasında katılımcıların oyunu bir öğrenme kaynağı olmaktan çok eğlenme aracı olarak gördükleri, arkadaşlarla oynanan, fiziksel aktiviteye dayalı dış mekân oyunlarından çok iç mekânlarda teknolojik ürünlerle ve oyunlarla daha çok oynadıklarını saptamıştır. Erbay ve Saltalı'nın ${ }^{17}$ altı yaş çocuklarının günlük yaşantılarında oyunun yeri ve annelerin oyun algısı adlı araştırmasında annelere çocukların okul dışındaki oyun etkinlikleri, oyun arkadaşları, oyun mekânları, oynadıkları oyunlar ve çocukların oyun etkinliklerini nasıl anlamlandırdıkları ile ilgili çeşitli sorular sorulmuştur. Araştırmanın sonucunda anneler çocukların okul dışı zamanlarının çoğunu televizyon izleyerek, kendi odasında salonda oyun oynayarak geçirdiklerini ifade etmişlerdir. Yine Özyürek ve Gürleyik' in ${ }^{18}$ yaptığı araştırmada anneler çocuğun gelişiminde oyunun önemini bilmelerine rağmen iş hayatında olmaları nedeniyle çocukları ile birlikte oyun oynamaya yeteri kadar vakit ayıramadiklarını belirtmişlerdir. İlgili araştırmada, anneler bu konudaki görüşlerini "çocuğum televizyon izliyor, arkadaşları ile oynamıyor, tablet oynuyor, müzik dinliyor" şeklinde belirtmişlerdir. Bu görüşler çocukların oyun oynamak için açık alanlara çıkmadıklarını daha çok kapalı mekânlarda teknolojik materyallerle oynamayı tercih ettiklerini göstermektedir. Koçyiğit ve Baydilek'in ${ }^{19}$ okul öncesi dönem çocuklarının oyun algılarının incelemeye yönelik yaptığı araştırmasında okul öncesi eğitimi alan çocuklar öğretmenlerinin oyunlarına katılmadıklarını, evde de

16 Belma Tuğrul - Gözde Ertürk - Şenay Özen Altınkaynak - Gökhan Güneş, a.g.e.

17 Filiz Erbay - Neslihan Durmuşoğlu Saltalı, "Altı Yaş Çocuklarının Günlük Yaşantılarında Oyunun Yeri ve Annelerin Oyun Algısı”, Ahi Evran Üniversitesi Kırşehir Eğitim Fakültesi Dergisi, cilt 13, say1 2, 2012, ss. 249-64.

18 Arzu Özyürek - Sevim Gürleyik, “Anne Babaların Okul Öncesi Dönem Çocukları İle Etkileşimlerinde Oyunun Yeri”, Journal of International Social Research, cilt 9, say1 42, 2016.

19 Sezai Koçyiğit - Nisa Başara Baydilek, "Okul Öncesi Dönem Çocuklarının Oyun Algılarının İncelenmesi”, Yüzüncü Yll Üniversitesi Eğitim Fakültesi Dergisi, cilt 12, say1 1, 2015, ss. 1-26. 
genelde yalnız oyun oynadıklarını söylemişlerdir. Duman ve Koçak'ın ${ }^{20}$ yaptığı çalışma oyun alanlarının kaydırak, tahterevalli ve tırmanma merdiveni gibi s1nırlı materyallerden oluşturulduğunu ve ilgi çekici, çocuğu doğa ile buluşturan, yaratıcılıklarını geliştiren dış mekân oyun alanlarına daha fazla ihtiyaç olduğu bulgusuna ulaşılmıştır. Z kuşağının iç mekânlarda daha fazla vakit geçirmesinde toplumsal hayatın değişmesiyle birlikte insanlar arasındaki etkileşim ve güvenin azalması, medya araçlarında çocuk istismarına yönelik olumsuz haberlerin daha hızlı yayılması ve çocukların ilgisini çeken dış mekân oyun alanlarının yetersizliği etkili olmuş olabilir. Valentine ve Mckendrick $^{21}$ şehirleşme ile birlikte artan güvenlik sorunlarının ve çocukların oyun mekanlarının olmamasının $Z$ kuşağının kapalı mekanlarda kalmalarında etkili olabileceğini belirtmiş̧tir. Z kuşağının oyunlarında kapalı mekânlarda televizyon izleme aktivitesinin ve bilgisayar oyunu oynamanın yoğun olarak görülmesi Clements' ${ }^{22}{ }^{22}$ araştırmasıyla tutarlılık göstermektedir. Clements araştırmasında Amerikalı Z kuşağı çocukların Y kuşağı annelerinden daha az dış mekanda zaman geçirdiklerini bu durumun televizyon ve dijital medya bağımlılığı sonucunu ortaya çıkardığını tespit etmiştir. Yine Alat, Akgümüş ve Cavalı'nın ${ }^{23}$ yaptıkları çalışmada öğretmenler, çocukların açık havada oyun oynamalarına ilişkin olumlu tutuma sahip olmalarına rağmen çocukların hastalanmalarından ve velilerin tepkilerinden dolayı açık hava etkinliklerine yeteri kadar yer veremediklerini ifade etmişlerdir. Velilerin bu yaklaşımı da öğretmenlerin çocukları kapalı oyun alanlarında oyun oynamalarını teşvik etmelerine neden olmuştur.

\section{Sonuç ve Öneriler}

Çalışmanın sonucuna göre $X$ kuşağı, oyunu çocuk işi ve çocuğun ihtiyacı olarak görürken $Y$ ve $Z$ kuşağı, eğlendirici faaliyet olarak tanımlamıştır. $X$ ve Y kuşağının oyun materyalleri çamur, toprak, taş, çubuk, sopa gibi doğal malzemelerden oluşurken, $Y$ ve $Z$ kuşağının oyun materyalleri arasında "top" yoğun

20 Gökhan Duman - Nurcan Koçak, "Çocuk Oyun Alanlarının Biçimsel Özellikleri Açısından Değerlendirilmesi (Konya İli Örneği)”, Türk Eğitim Bilimleri Dergisi, cilt 11, sayı 1, 2013, ss. 64-81.

21 Gill Valentine - John Kendrick, "Children's outdoor play: Exploring parntal concerns about children's safety and the changing nature of childhood", Geoforum, cilt 28, say1 2, 1997, ss. 219-235.

22 Rhonda Clements, "An investigation of the status of outdoor play", Contemporary Issues in Early Childhood, cilt 5, say1 1, 2004, ss. 68-80.

23 Zeynep Alat - Özlem Akgümüş - Didem Cavalı, "Okul Öncesi Eğitimde Açık Hava Etkinliklerine Yönelik Öğretmen Görüş ve Uygulamaları”, Mersin Üniversitesi Eğitim Fakültesi Dergisi, cilt 8, say1 3, 2012, ss. 47-62. 
olarak kullanılmıştır. Z kuşağının oyun materyallerinde oyuncaklar, bebekler, boya kalemleri gibi endüstriyel ve yapay oyun materyalleri de görülmektedir. $\mathrm{X}$ ve $\mathrm{Y}$ kuşağının oyun alanlarını açık oyun alanları oluştururken $Z$ kuşağının oyunlarında kapalı mekânlar tercih edilmiştir. Z kuşağının oyunlarında evcilik, bilgisayar oyunları ve televizyon izlemek gibi teknolojik oyunlar ve aktiviteler de yoğun olarak yer almıştır. Çocukların oyunları X ve $\mathrm{Y}$ kuşaklarından $\mathrm{Z}$ kuşağına doğru diş mekanlardan iç mekanlara, doğal materyallerden endüstriyel ve yapay materyallere evrilse de bütün kuşakların oyunlarında saklambaç, mendil kapmaca, çelik çomak, körebe, ip atlama gibi geleneksel oyunlar farklı düzeylerde görülmektedir.

$\mathrm{Bu}$ araştırma, kadınların yoğun olduğu bir çalışma grubuyla yapılmıştır. X, Y, Z kuşaklarında farklı cinsiyet ve farklı bölgelerden katılımcılar ile yapılarak hem nitel hem de nicel farklı araştırmalar yapılabilir. Ayrıca çocukluğunu 2015 yılından sonra tablet ve akıllı telefonların daha yoğun olduğu dönemde geçiren $\mathrm{Z}$ kuşağının oyun davranışları gözlemlenebilir ve oyunları materyalleri, oyun alanları incelenebilir. 


\section{Kaynakça}

Akçay, Duygu - Özcebe, Hilal, "Okul Öncesi Eğitim Alan Çocukların ve Ailelerinin Bilgisayar Oyunu Oynama Alışkanlıklarının Değerlendirilmesi”, Çocuk Dergisi, cilt 12, say1 2, 2012.

Aksoy, Ayşe Belgin - Dere Çiftçi, Hale, "Oyun Alanı Materyal ve Oyuncaklar”, Okul Öncesi Ĕ̆itimde Oyun, editör Ayşe Belgin Aksoy, Ankara, Hedef, 2015.

Alat, Zeynep - Akgümüş, Özlem - Caval1, Didem "Okul Öncesi Eğitimde Açık Hava Etkinliklerine Yönelik Öğretmen Görüş ve Uygulamaları”, Mersin Üniversitesi Ĕ̈itim Fakültesi Dergisi, cilt 8, say1 3, 2012.

Başgöze, Pınar - Bayar, Nalan, "Eko Otellerden Hizmet Satın Alımında Kuşaklar Arası Farklılaşmalar Üzerine Bir Çalışma”, Sosyoekonomi, cilt 23, sayı 24, 2015.

Baykoç Dönmez, Necate, Oyun Kitabı, İstanbul, Esin Yayınevi, 1992.

Berg, Buruce L. - Lune, Howard, Sosyal Bilimlerde Nitel Araştırma Yöntemleri, çeviri editörü Hasan Aydın, Konya, Eğitim Yayınevi, 2015.

Binbaşıŏlu, Cavit, "Çocuk Eğitiminde Oyun”, Çăğdaş Eğitim Dergisi, sayı 231, 1997.

Büyüköztürk, Şener - Kılıç Çakmak, Ebru - Akgün, Özcan Erkan - Karadeniz, Şirin - Demirel, Funda, "Bilimsel Araştırma Yöntemleri”, 13. bs., Ankara, PegemAkademi, 2012.

Cleland, Verity - Crawford, David - Baur, Louise - Hume, Clare - Timperio, Anne - Salmon, Jo, “A prospective examination of children's time spent outdoors, objectively measured physical activity and overweight, Children's time outdoors, activity and overweight", International Journal of Obesity, sayı 32, 2008.

Clements, Rhonda, "An investigation of the status of outdoor play", Contemporary Issues in Early Childhood, cilt 5, say1 1, 2004.

Dawson, Catherine, Araştırma Yöntemlerine Giriş, çeviri editörü Asım Arı, Konya, Eğitim Yayınevi, 2015.

Duman, Gökhan - Koçak, Nurcan, "Çocuk Oyun Alanlarının Biçimsel Özellikleri Açısından Değerlendirilmesi (Konya İli Örneği)”, Türk Ĕgitim Bilimleri Dergisi, cilt 11, sayı 1, 2013.

Erbay, Filiz - Durmuşoğlu Saltalı, Neslihan, “Altı Yaş Çocuklarının Günlük Yaşantılarında Oyunun Yeri ve Annelerin Oyun Algısı", Ahi Evran Üniversitesi Kırşehir Eğitim Fakültesi Dergisi, cilt 13, sayı 2, 2012. 
Goodwin, Kristy, Dijital Dünyada Çocuk Büyütmek, çeviri Tülin Er, İstanbul, Aganta, 2018.

Koçyiğit, Sezai - Başara Baydilek, Nisa, "Okul Öncesi Dönem Çocuklarının Oyun Algılarının İncelenmesi”, Yüzüncü Yıl Üniversitesi Eğitim Fakültesi Dergisi, cilt 12, say1 1, 2015.

McCrindle, Mark - Wolfinger, Emily, The Abc of Xyz: Understanding the Global Generations, Avustralya, University of New South Wales, 2009.

Özdemir, Nebi, Türk Çocuk Oyunları, Ankara, Akçağ Yayınları, 2006.

Özyürek, Arzu - Gürleyik, Sevim, “Anne Babaların Okul Öncesi Dönem Çocukları İle Etkileşimlerinde Oyunun Yeri”, Journal of International Social Research, cilt 9, say1 42, 2016.

Poyraz, Hatice, Okul Öncesi Dönemde Oyun ve Oyuncak, Ankara, Anı Yayınc1lik, 2003.

TDK, Türk Dil Kurumu Sözlügü, https://tdk.gov.tr/, 2019.

Tuğrul, Belma, “Oyunun Gücü”, Okul Öncesi Eğitimde Oyun, editör Ayşe Belgin Aksoy, Ankara, Hedef, 2015.

Tuğrul, Belma - Ertürk, Gözde - Özen Altınkaynak, Şenay - Güneş, Gökhan, "Oyunun Üç Kuşaktaki Değişimi", The Journal of Academic Social Science Studies, say1 27, 2014.

Valentine, Gill - Kendrick, John, “Children's outdoor play: Exploring parntal concerns about children's safety and the changing nature of childhood", Geoforum, cilt 28, say1 2, 1997.

Yıldırım, Ali - Şimşek, Hasan, Nitel Araştırma Yöntemleri, 2. bs., Ankara, Seçkin Yayıncılık, 2000. 